\title{
DAYA REGENERASI KALUS DAN TUNAS IN VITRO PADI VARIETAS TARABAS PADA BERBAGAI KONSENTRASI 2,4-D
}

\section{In Vitro Callus and Plant Regeneration Rate of Tarabas Rice on Several Concentrations of 2,4-D}

\author{
Wahyu Indra Duwi Fanata ${ }^{1,2 *}$, Dalliyah Hadrotul Qudsiyah' \\ ${ }^{1}$ Program Studi Agroteknologi, Fakultas Pertanian, Universitas Jember, Jl. Kalimantan 37, Kampus \\ Tegalboto, Sumbersari, Jember 68121 \\ ${ }^{2}$ Center for Development of Advanced Science and Technology (CDAST) Universitas Jember \\ Jl. Kalimantan 37, Kampus Tegalboto, Sumbersari, Jember 68121 \\ `Email: wahyuindra.faperta@unej.ac.id
}

\begin{abstract}
The Agricultural Research and Development Agency and the West Java Provincial Government are developing new superior varieties with Japonica rice standards, namely the Tarabas variety. However, the equivalence of somatic embryogenesis ability of Tarabas rice with original Japonica variety has not been reported. In this study, the frequency of callus regeneration of Tarabas vs Hwayoung rice varieties was compared. Induction of callus from mature embryos with several concentrations of 2,4-D showed the same extent of callus formation in both rice varieties. Callus induced by $1 \mathrm{ppm}$ of 2,4-D showed the higher rate of shoot formation. On the other hand, percentage of callus formation of Tarabas rice was not affected by the increase of 2,4-D concentrations and was able to show $100 \%$ regeneration rate at the fourth week in the regeneration medium, although the shoot growth was not as fast as those from medium with $1 \mathrm{ppm} 2,4-D$. Therefore, these results suggest that Tarabas variety has a somatic embryogenesis capacity equivalent to that of japonica rice and has the potential as research objects in the field of biotechnology.
\end{abstract}

Keywords: 2,4-D, callus, in vitro, regeneration, Tarabas

\begin{abstract}
ABSTRAK
Badan Penelitian dan Pengembangan Pertanian serta Pemerintah Provinsi Jawa Barat mengembangkan varietas unggul baru dengan standar padi Japonica yaitu varietas Tarabas. Namun, kesetaraan varietas Tarabas dengan varietas Japonica asli dalam kemampuan embriogenesis somatik belum dilaporkan. Penelitian ini membandingkan respons kultur jaringan antara beras Tarabas dan padi Japonica varietas Hwayoung. Induksi kalus dari embrio matang dengan beberapa konsentrasi 2,4-D menunjukkan respons pembentukan kalus yang sama pada kedua varietas padi. Kalus yang diinduksi 1 ppm 2,4-D menunjukkan laju pembentukan tunas yang lebih tinggi. Di sisi lain, kalus Hwayoung yang diinduksi konsentrasi 2,4-D yang lebih tinggi menunjukkan penghambatan dalam pembentukan tunas. Di lain pihak, pembentukan kalus padi Tarabas tidak terpengaruh oleh peningkatan konsentrasi 2,4-D dan mampu menunjukkan $100 \%$ laju regenerasi tanaman pada minggu keempat di media regenerasi walaupun pertumbuhan tunas tidak secepat pada perlakuan 1 ppm 2,4-D. Karena itu, hasil penelitian ini menunjukkan bahwa varietas Tarabas memiliki kapasitas embriogenesis somatik yang setara dengan padi japonica dan padi Tarabas mempunyai potensi sebagai obyek penelitian di bidang bioteknologi.
\end{abstract}

Kata Kunci: 2,4-D, in vitro, kalus, regenerasi, Tarabas 


\section{PENDAHULUAN}

Tanaman padi (Oryza sativa) merupakan salah satu tanaman sereal yang paling banyak dibudidayakan oleh negaranegara di dunia. Beras sebagai produk tanaman padi berkontribusi $20 \%$ bagi pemenuhan kalori harian masyarakat dunia terutama pada negara-negara berkembang (Fraiture et al. 2016). Usaha pemenuhan kebutuhan beras yang semakin meningkat sedang menghadapi berbagai macam tantangan, terutama disebabkan menurunnya produktivitas yang disebabkan oleh semakin tidak idealnya lingkungan tumbuh tanaman padi. Berbagai inisiatif melalui pemanfaatan bioteknologi telah dilakukan untuk meningkatkan produktivitas tanaman padi melalui pendekatan rekayasa genetika demi terjaganya ketahanan pangan masyarakat (Ahmad et al. 2012, He et al. 2014). Transformasi genetik merupakan salah satu perangkat bioteknologi terpenting bagi usaha perbaikan sifat tanaman dan keberhasilannya sangat bergantung pada efisiensi teknik kultur jaringan yang digunakan (Sidorov 2013, Mohammed et al. 2019).

Beberapa faktor penentu utama bagi keberhasilan kultur jaringan tanaman antara lain genotip, jenis eksplan, zat pengatur tumbuh, dan kondisi lingkungan kultur (Rahman et al. 2015). Auksin sintetik dalam bentuk 2,4-D sangat efektif untuk penginduksian kalus dari embrio padi sedangkan sitokinin dalam bentuk kinetin atau 6-benzylaminopurine (BAP) umumnya digunakan sebagai penginduksi tunas dari kalus (Fanata et al. 2013). Penggunaan jenis eksplan untuk pembentukan kalus merupakan salah satu pembeda utama pada berbagai metode kultur jaringan pada tanaman padi. Eksplan berupa biji padi yang telah masak umum digunakan dan telah diketahui memberikan respons regenerasi kalus embriogenik dan embriosomatik yang sangat baik (Wani et al. 2011, Sah dan Kaur 2013). Kalus padi yang bersifat embriogenik umumnya berwarna kekuningan dan berasal dari jaringan skutelum biji yang masak (Sahoo et al. 2011). Beberapa hasil penelitian menunjukkan bahwa kualitas kalus sangat dipengaruhi oleh konsentrasi 2,4-D yang diberikan pada proses induksi kalus. Penggunaan 2,4-D pada konsentrasi yang rendah menghasilkan kalus embriogenik yang lebih tinggi pada jenis padi dataran tinggi (upland rice), sedangkan penggunaan 2,4-D pada konsentrasi yang lebih tinggi memberikan efek penghambatan dalam pembentukan dan regenerasi kalus (Zhao et al. 2011). Media induksi yang mengandung 1 dan $2 \mathrm{mg} / \mathrm{L}$ 2,4-D menghasilkan kalus embriogenik yang lebih tinggi, sedangkan konsentrasi 3, 4, dan $5 \mathrm{mg} / \mathrm{L}$ menghasilkan kalus yang lebih kecil dan mudah hancur (Libin et al. 2012).

Untuk keperluan perakitan tanaman padi transgenik, kalus yang diinduksi dari embrio yang sudah matang (mature embryo) umumnya digunakan untuk proses transformasi genetik menggunakan bakteri Agrobacterium tumefaciens (Hiei dan Komari 2008). Kalus yang diinduksi dari padi japonica mempunyai daya pembentukan kalus dan kemampuan beregenerasi lebih tinggi dibandingkan dengan padi indica (Ali et al. 2004). Kalus padi japonica varietas Kitaake menghasilkan tingkat regenerasi sebesar $82,66 \%$ berbanding $9,6 \%$ pada kalus padi indica varietas Ciherang (Sah et al. 2014a, Azizah et al. 2017). Hal ini kemudian menyebabkan padi dari golongan japonica lebih banyak digunakan dalam kegiatan transformasi genetik untuk tujuan analisa fungsi gen maupun pembentukan varietas unggul (Sah et al. 2014b).

Badan Litbang Pertanian bekerjasama dengan Pemerintah Provinsi Jawa Barat telah merilis padi Tarabas sebagai varietas unggul baru nasional. Padi ini menghasilkan beras dengan bentuk bulir yang membulat serta kadar amilosa rendah (17,73\%), sehingga nasi yang dihasilkan bersifat pulen dan lengket (sticky). Padi varietas Tarabas memiliki beberapa kelemahan seperti produktivitasnya yang masih rendah $(4,1$ ton/Ha), sangat rentan terhadap serangan penyakit hawar daun bakteri strain IV dan VIII, dan peka wereng batang coklat biotipe 1 . Padi jenis japonica pada umumnya mempunyai kandungan amilosa kurang dari $20 \%$ sedangkan kadar amilosa minimal pada padi indica adalah 20\% (Feng et al. 2017). Berdasarkan hal tersebut, maka padi Tarabas kemudian digolongkan ke dalam jenis japonica.

Sifat japonica padi Tarabas juga perlu diverifikasi melalui pengujian dalam hal respons pembentukan kalus dan embryogenesis secara in vitro. Kondisi kultur 
jaringan yang ideal untuk padi Tarabas selanjutnya menjadi faktor penentu bagi keberhasilan perbaikan sifat padi Tarabas melalui bioteknologi. Pada penelitian ini, daya pembentukan kalus padi Tarabas diuji melalui penggunaan beberapa konsentrasi 2,4-D. Kalus yang dihasilkan oleh masing-masing konsentrasi 2,4-D kemudian diuji kemampuan embryogenesis dan daya regenerasinya menjadi tanaman. Padi japonica varietas Hwayoung digunakan sebagai pembanding pada seluruh pengujian yang telah dilakukan.

\section{BAHAN DAN METODE}

\section{Tempat dan waktu penelitian}

Penelitian dilaksanakan pada bulan Januari 2020 sampai Maret 2020 di Divisi Biologi Molekuler dan Bioteknologi, Center for Development of Advance Science and Technology (CDAST), Universitas Jember.

\section{Bahan tanam dan sterilisasi eksplan}

Bahan tanam yang digunakan dalam penelitian ini adalah benih padi varietas Tarabas dan Hwayoung. Biji padi varietas Tarabas dan Hwayoung yang telah dipisahkan kulit gabahnya yang telah masak dengan kondisi embrio yang utuh dan secara visual tidak berjamur disterilisasi terlebih dahulu dengan cara menggojoknya dua kali dalam larutan hipoklorit $1 \%$ dengan durasi 10 menit untuk masing-masing tahap penggojokan. Biji padi kemudian dibilas

Tabel 1. Bahan-bahan penyusun media kultur jaringan yang digunakan

\begin{tabular}{lcc}
\hline $\begin{array}{l}\text { Komponen } \\
\text { Penyusun } \\
\text { Media }\end{array}$ & $\begin{array}{c}\text { Media } \\
\text { Induksi } \\
\text { Kalus (1L) }\end{array}$ & $\begin{array}{c}\text { Media } \\
\text { Regenerasi } \\
\text { Tunas (1L) }\end{array}$ \\
\hline N6 salt & $4 \mathrm{~g}$ & $4 \mathrm{~g}$ \\
Sukrosa & $30 \mathrm{~g}$ & $30 \mathrm{~g}$ \\
Kasein & $1 \mathrm{~g}$ & $0,3 \mathrm{~g}$ \\
Prolin & $0,5 \mathrm{~g}$ & $0,5 \mathrm{~g}$ \\
Glutamin & $0,5 \mathrm{~g}$ & $0,5 \mathrm{~g}$ \\
N6 vitamin (1000×) & $1 \mathrm{~mL}$ & $1 \mathrm{~mL}$ \\
2,4-D & $1,2,3, \mathrm{dan} 4 \mathrm{ppm}$ & - \\
Kinetin & $2 \mathrm{ppm}$ & - \\
BAP & - & $2 \mathrm{ppm}$ \\
NAA & - & $0,5 \mathrm{ppm}$ \\
Gelrite & $4 \mathrm{~g}$ & $7,5 \mathrm{~g}$ \\
pH & 5,8 & 5,8 \\
\hline
\end{tabular}

dengan aquades steril melalui proses penggojokan selama 3 menit. Proses pembilasan diulang 5 kali atau sampai dengan bau hipoklorit menghilang.

\section{Rancangan percobaan dan analisa data}

Rancangan percobaan dalam penelitian ini menggunakan rancangan acak lengkap (RAL) dengan dua faktor. Faktor pertama yakni dua varietas padi dan faktor kedua yakni empat taraf konsentrasi 2,4-D. Metode analisis yang digunakan adalah uji-F dan dilakukan uji lanjut DMRT (Duncan Multiple Range Test) dengan taraf 5\% jika terdapat perbedaan nyata.

\section{Media kultur jaringan}

Media kultur jaringan yang digunakan dibuat dengan melarutkan bahan-bahan yang tertera pada Tabel 1.

Larutan media disterilisasi menggunakan autoklaf pada suhu $121^{\circ} \mathrm{C}$ selama 15 menit dengan tekanan 17,5 psi. Media yang telah steril dituang ke dalam cawan petri steril sebanyak kurang lebih 30 $\mathrm{mL}$ dan dibiarkan hingga media memadat.

\section{Penanaman dan inkubasi eksplan}

Biji padi steril ditanam pada media induksi kalus padat dan diinkubasi pada suhu $28^{\circ} \mathrm{C}$ selama 15 hari dalam kondisi gelap. Kalus yang terbentuk kemudian dipindahkan ke media regenerasi untuk selanjutnya ditumbuhkan dalam growth chamber pada suhu $28^{\circ} \mathrm{C}$ dengan kondisi penyinaran harian 16 jam pencahayaan $\left(200 \mu \mathrm{mol} / \mathrm{m}^{2} /\right.$ detik) dan 8 jam kondisi gelap.

\section{Pengamatan kalus dan regenerasi tanaman}

Respons kultur jaringan biji padi Tarabas dan Hwayoung dianalisa melalui beberapa variabel sebagai berikut: persentase eksplan yang membentuk kalus, persentase kalus yang membentuk meristemoid berwarna hijau (spot hijau), dan persentase kalus yang beregenerasi menjadi tunas. Persentase eksplan yang membentuk kalus pada hari ke-15 pada media induksi kalus dihitung dengan rumus:

$$
\begin{gathered}
\% \text { Eksplan berkalus }= \\
\frac{\sum E \text { Esplan biji berkalus }}{\sum \text { Seluruh biji ditanam }} \times 100 \%
\end{gathered}
$$


Persentase kalus yang membentuk spot hijau pada media regenerasi dihitung pada minggu pertama dan minggu kedua dengan rumus (Libin et al. 2012):

$\%$ Kalus membentuk spot hijau $=$

$$
\frac{\sum \text { Kalus spot hijau }}{\sum \text { Kalus ditanam }} \times 100 \%
$$

Persentase kalus yang membentuk tunas pada media regenerasi tunas dihitung pada minggu ketiga, keempat dan kelima dengan menggunakan rumus:

$$
\begin{aligned}
& \% \text { Kalus membentuk tunas }= \\
& \frac{\sum \text { Kalus bertunas }}{\sum \text { Kalus ditanam }} \times 100 \%
\end{aligned}
$$

Analisa morfologi kalus dan tunas yang terbentuk dilakukan dengan menggunakan mikroskop stereo.

\section{HASIL DAN PEMBAHASAN}

\section{Persentase pembentukan kalus}

Penambahan auksin pada media induksi akan menstimulasi pembelahan sel secara terus-menerus untuk membentuk jaringan kalus pada eksplan. Keberhasilan dalam induksi kalus pada biji padi diindikasikan dengan adanya pembengkakan pada bagian skutelum. Pemberian 2,4-D pada media induksi kalus mampu menghasilkan kalus embriogenik, meskipun tanpa adanya kombinasi dengan zat pengatur tumbuh lainnya (Shahsavari et al. 2010).

Jenis dan konsentrasi auksin yang diberikan pada media induksi dapat mempengaruhi perkembangan sel-sel dalam kalus padi (Binte Mostafiz dan

Tabel 2. Persentase pembentukan kalus padi Tarabas dan Hwayoung pada beberapa konsentrasi $2,4-D$. Nilai yang diikuti oleh huruf berbeda menunjukkan perbedaan yang nyata pada uji DMRT dengan taraf $5 \%$.

\begin{tabular}{lcccc}
\hline \multirow{2}{*}{ Varietas } & \multicolumn{4}{c}{ Konsentrasi 2,4-D (ppm) } \\
\cline { 2 - 5 } & $1(\mathrm{~K} 1)$ & $2(\mathrm{~K} 2)$ & $3(\mathrm{~K} 3)$ & $4(\mathrm{~K} 4)$ \\
\hline $\begin{array}{l}\text { Hwayoung } \\
\text { (V1) }\end{array}$ & $98,3 \% \mathrm{a}$ & $100 \% \mathrm{a}$ & $100 \% \mathrm{a}$ & $96 \% \mathrm{~b}$ \\
$\begin{array}{l}\text { Tarabas } \\
\text { (V2) }\end{array}$ & $100 \% \mathrm{a}$ & $100 \% \mathrm{a}$ & $98,3 \% \mathrm{a}$ & $98,3 \% \mathrm{a}$ \\
\hline
\end{tabular}

Wagiran 2018). Tingginya konsentrasi 2,4D yang diberikan dapat menjadi penghambat induksi kalus serta memicu proses pencoklatan. Berdasarkan Tabel 2, hasil analisis pada induksi kalus padi Hwayoung dan Tarabas menunjukkan pada konsentrasi yang lebih rendah mampu menghasilkan persentase pembentukan kalus lebih tinggi. Persentase pembentukan kalus tertinggi yakni $100 \%$ ditunjukkan oleh perlakuan V1K2, V1K3, V2K1 dan V2K2, sedangkan persentase terendah yakni pada perlakuan V1K4 sebesar 96\%. Hasil pengamatan induksi kalus pada hari ke-15 menunjukkan bahwa kalus varietas Hwayoung dan Tarabas secara morfologi tidak menunjukkan perbedaan setelah diinduksi oleh beberapa konsentrasi 2,4-D. Kalus yang terbentuk memiliki bentuk dan ukuran yang tidak berbeda pula. Berdasarkan Gambar 1A, dapat diketahui bahwa biji kedua varietas padi mampu untuk membentuk kalus pada semua konsentrasi 2,4-D yang diberikan.

Kalus padi Hwayoung dan Tarabas yang dihasilkan melalui proses induksi kalus oleh 2,4-D mampu membentuk kalus yang bersifat embriogenik seperti pada Gambar 1B. Pada hari ke-15 kalus yang terbentuk masih berupa kalus primer yang diinduksi dari jaringan skutelum biji padi. Kalus embriogenik memiliki ciri-ciri antara lain strukturnya berbentuk nodular, padat, kering, serta berwarna putih atau kekuningan, sedangkan kalus non-embriogenik tampak basah, berwarna kuning muda sampai kecoklatan, dan non nodular (Hoque et al. 2007).

\section{Persentase kalus yang membentuk spot hijau}

Kalus yang telah berumur 15 hari selanjutnya dipindahkan ke media regenerasi dan ditempatkan dalam growth chamber dengan durasi penyinaran harian selama 16 jam. Pemindahan kalus pada kondisi terang akan memicu pembentukan spot hijau. Dalam kondisi ketercukupan cahaya, sitokinin dapat menginduksi pembentukan kloroplas pada organ tanaman (Cortleven dan Schmülling 2015). Pengamatan spot hijau pada kalus dilakukan setiap minggu setelah kalus dipindah ke media regenerasi. Berdasarkan Gambar 2 dapat diketahui varietas Hwayoung memiliki kemampuan membentuk spot hijau lebih rendah daripada 
varietas Tarabas, hal ini tampak jelas pada pengamatan minggu pertama. Selain itu, kombinasi perlakuan varietas dengan konsentrasi $1 \mathrm{ppm}$ 2,4-D lebih cepat membentuk spot hijau dibandingkan dengan konsentrasi 2,4-D yang lebih tinggi. Semakin rendah konsentrasi 2,4-D yang diberikan, maka semakin tinggi kemampuan sel kalus untuk membentuk spot hijau. Kemampuan dalam membentuk spot hijau merupakan salah satu indikator keberhasilan proses regenerasi kalus menjadi tanaman (Ben Amer dan Börner 1997).

A
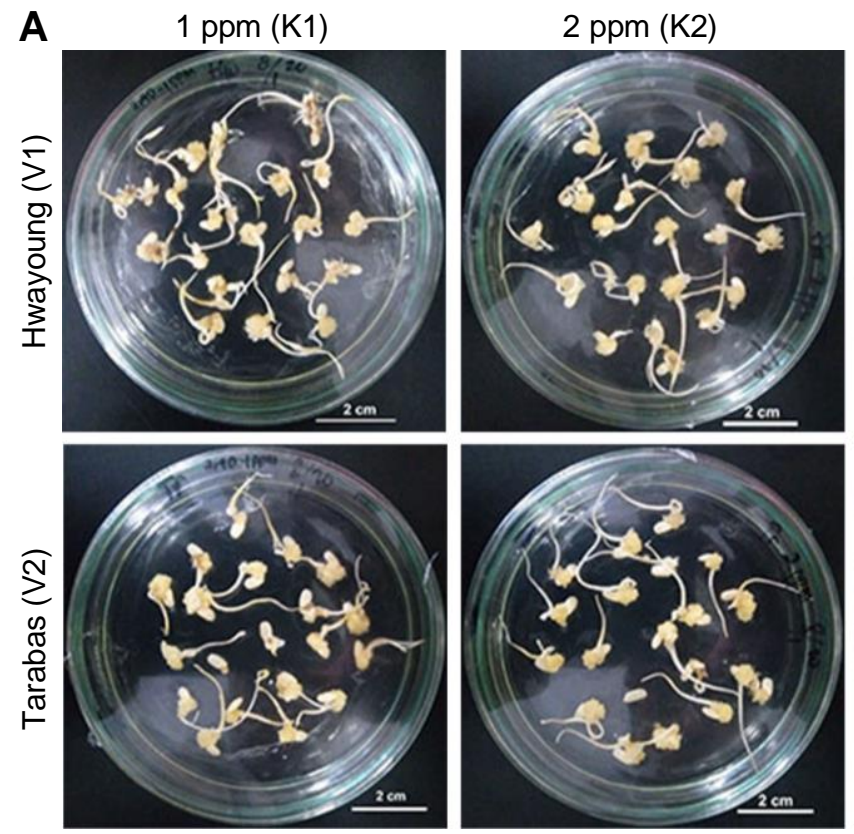

B
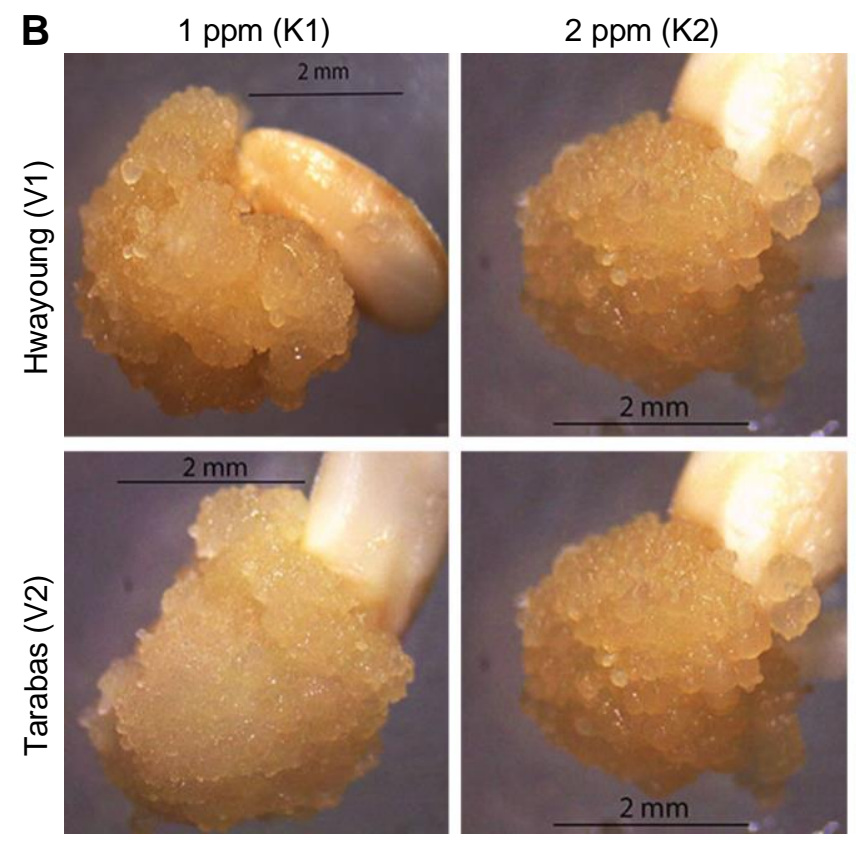

\section{Daya regenerasi kalus menjadi tanaman}

Kenampakan pembentukan spot hijau dan regenerasi pada kalus setiap minggu dapat diamati, seperti yang tampak pada Gambar 3. Kalus yang telah disubkultur pada media regenerasi maka akan memasuki fase pembentukan spot hijau dan regenerasi tunas. Tampak pada minggu ke-1, kalus pada beberapa titik tampak menghijau. Kemudian pada minggu ke-2 terdapat spot-spot berwarna hijau yang semakin jelas, bahkan pada varietas Tarabas dengan konsentrasi 1 ppm 2,4-D telah menunjukkan adanya
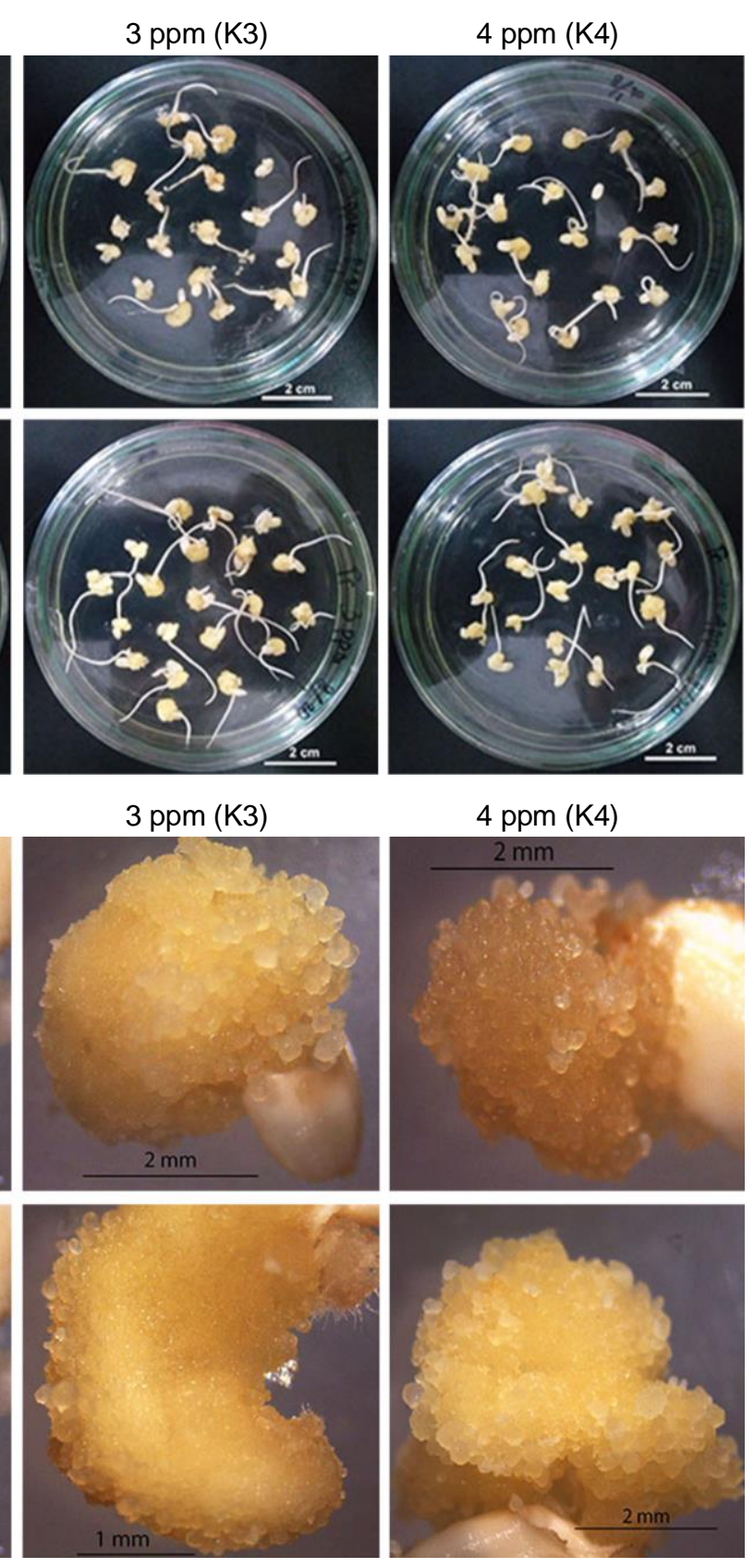

Gambar 1. Pembentukan kalus setelah masa inkubasi selama 15 hari. (A) Hasil induksi kalus varietas Hwayoung dan Tarabas dengan beberapa konsentrasi 2,4-D umur 15 HST (B) Kenampakan kalus varietas Hwayoung dan Tarabas yang diinduksi oleh beberapa konsentrasi 2,4-D secara mikroskopis pada umur 15 HST 


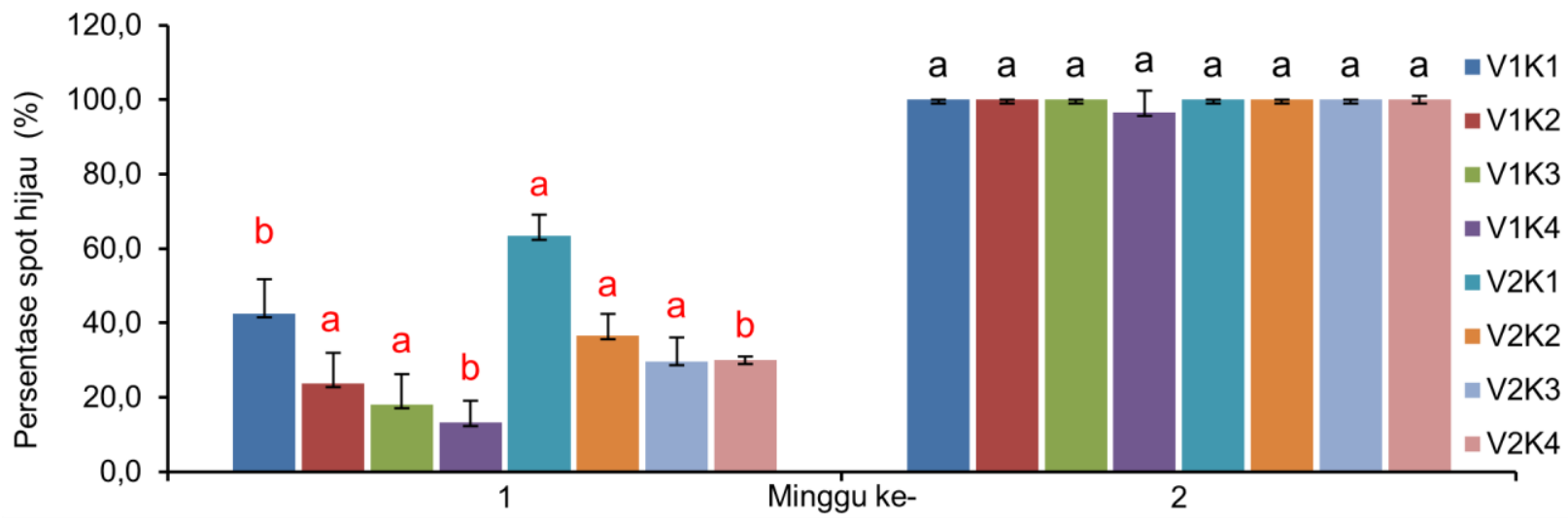

Gambar 2. Hasil pengamatan daya pembentukan spot hijau kalus setiap minggu. Huruf berbeda menunjukkan perbedaan yang nyata menurut uji DMRT pada taraf $5 \%$
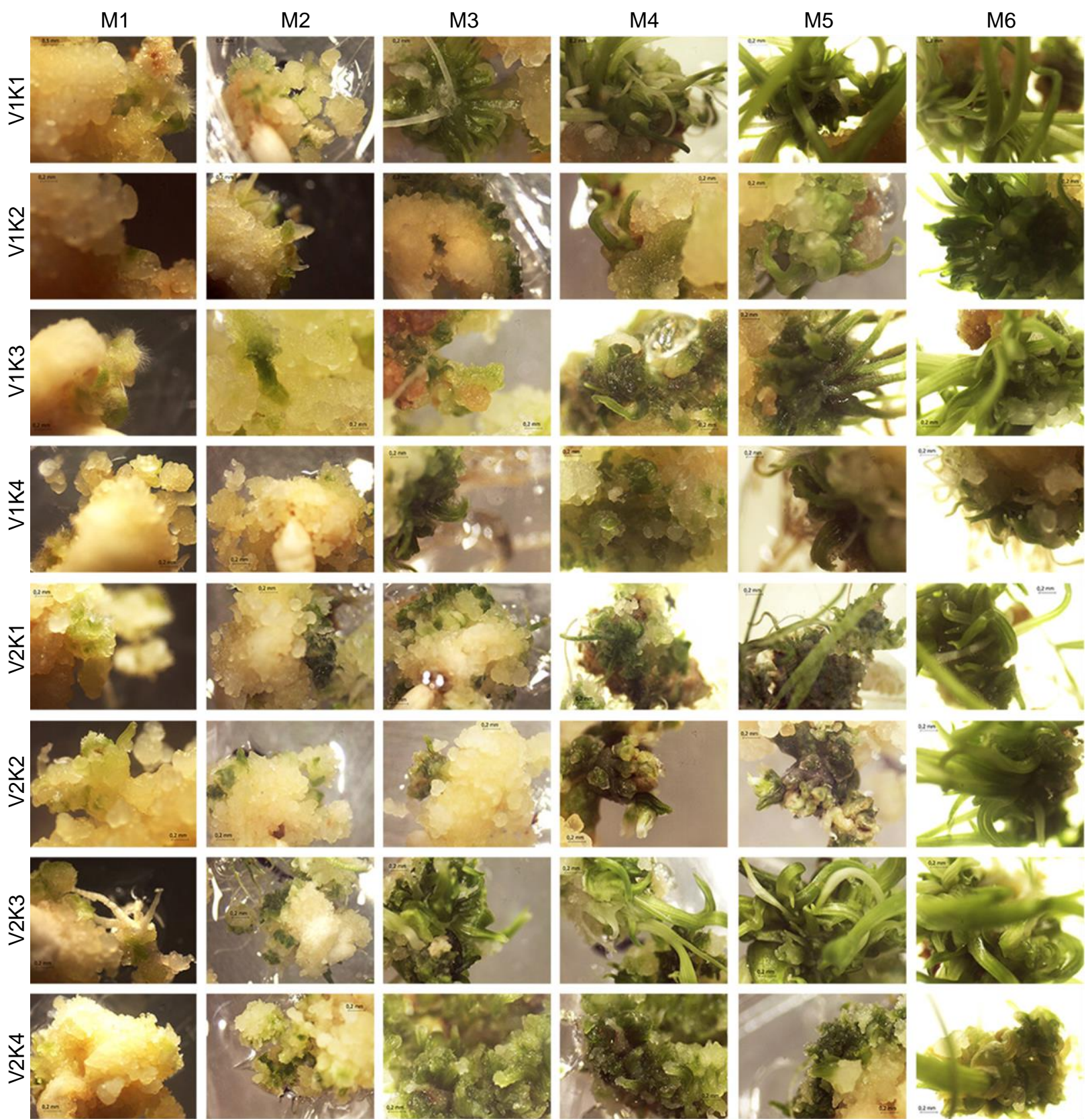

Gambar 3. Kenampakan spot hijau dan regenerasi tanaman dari kalus setiap minggu setelah subkultur. M adalah minggu 
pertumbuhan tunas. Selanjutnya, pada minggu ke-3 hingga ke-5 spot-spot hijau berkembang menjadi tunas yang selanjutnya muncul bagian daun dan akar.

Regenerasi kalus menjadi tanaman pada umumnya ditandai dengan munculnya tunas dari nodul hijau atau spot hijau yang telah terbentuk. Tunas selanjutnya akan memanjang membentuk batang dan daun. Kalus yang bersifat embriogenik telah diketahui mengandung hormon auksin dan sitokinin endogen yang tinggi dan interaksi antara hormon endogen kalus dan ZPT eksogen berperan penting terhadap keberhasilan proses regenerasi kalus menjadi tanaman (Huang et al. 2012, Lee dan Huang 2014). Pada pengamatan daya regenerasi tanaman pada minggu ketiga dan keempat, dapat diidentifikasi bahwa kalus padi Tarabas menunjukkan kemampuan beregenerasi yang lebih tinggi dibandingkan dengan kalus padi Hwayoung (Gambar 4A). Dapat diidentifikasi juga bahwa kalus padi Tarabas yang diinduksi oleh keempat perlakuan 2,4-D mempunyai kemampuan pembentukan tunas yang sama. Sebaliknya, hambatan pembentukan tunas dapat diamati pada kalus padi Hwayoung yang diinduksi oleh 2,4-D pada konsentrasi yang semakin tinggi. Pada pengamatan minggu kelima, seluruh kalus pada semua perlakuan menunjukkan tingkat regenerasi $100 \%$, terkecuali pada kalus padi Hwayoung yang diinduksi oleh 4 ppm 2,4-D. Walaupun seluruh kalus dapat membentuk tunas pada minggu kelima, secara visual dapat diamati

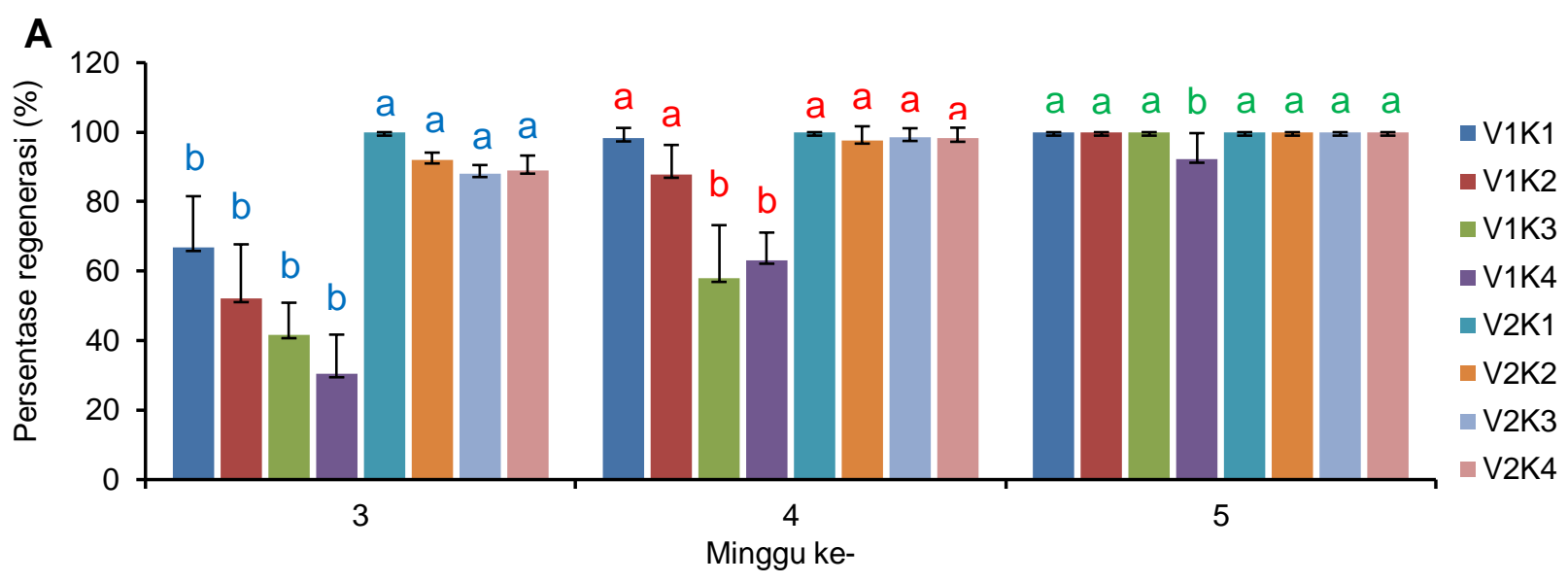

B
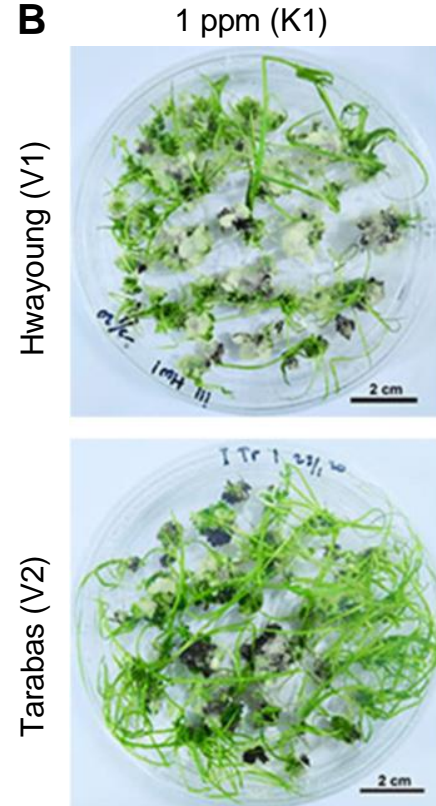

$2 \mathrm{ppm}(\mathrm{K} 2)$
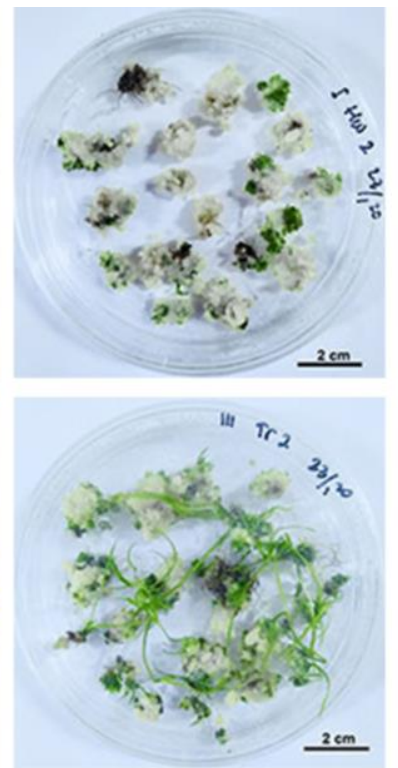

3 ppm (K3)
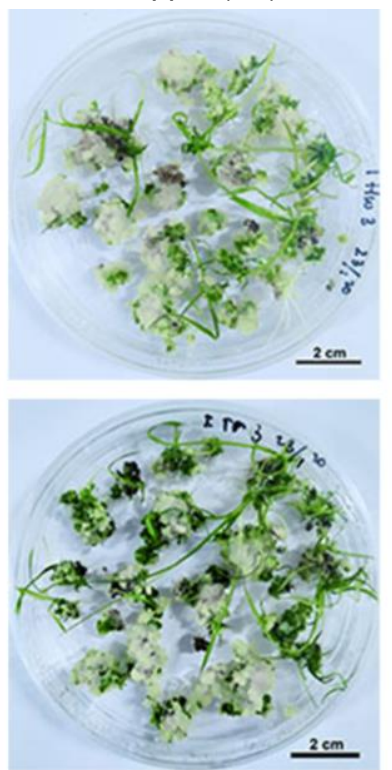

4 ppm (K4)
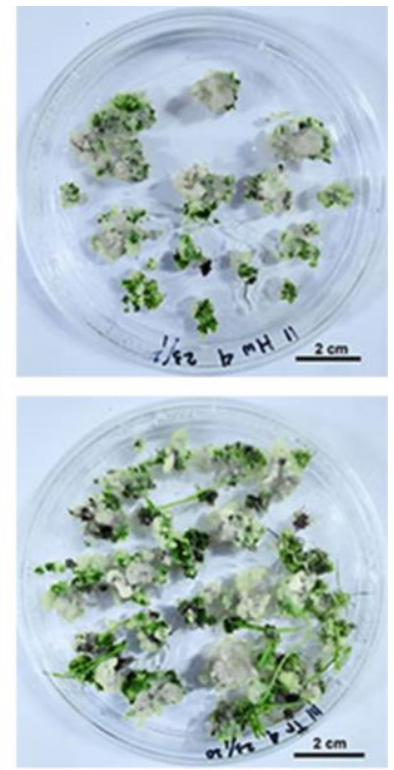

Gambar 4. Regenerasi tanaman dari kalus padi varietas Hwayoung dan Tarabas setelah subkultur (A) Hasil pengamatan daya regenerasi tanaman dari kalus padi varietas Hwayoung dan Tarabas setiap minggu. Huruf berbeda menunjukkan perbedaan yang nyata menurut uji DMRT pada taraf $5 \%$. (B) Kenampakan tanaman nadi dari kalus nada media recenerasi tunas Minanu ke-5 
dengan jelas bahwa kalus yang diinduksi oleh 1 ppm 2,4-D pada kedua varietas mempunyai tunas yang lebih panjang dibandingkan dengan kalus yang diinduksi oleh 2,4-D dengan konsentrasi lebih tinggi (4B). Residu 2,4-D dalam kalus yang ditumbuhkan pada media regenerasi telah dilaporkan memberikan efek penghambatan bagi proses regenerasi tunas. Kalus yang dihasilkan oleh media induksi dengan 1 ppm 2,4-D menunjukkan tingkat regenerasi yang lebih tinggi pada beberapa varietas elit Pakistan (Mitsuoka et al. 1994, Joyia dan Khan 2013).

\section{KESIMPULAN}

Ekplan biji padi masak varietas Tarabas memiliki kemampuan regenerasi kalus yang sama dengan padi japonica varietas Hwayoung. Sedangkan pada tahap regenerasi tanaman, kalus padi varietas Tarabas memiliki kemampuan lebih tinggi dibandingkan dengan varietas Hwayoung. Pemberian 2,4-D konsentrasi 1 ppm menghasilkan respons regenerasi terbaik pada varietas Tarabas dan Hwayoung.

\section{UCAPAN TERIMA KASIH}

Ucapan terima kasih ditujukan kepada Universitas Jember yang telah mendanai penelitian ini melalui Surat Keputusan Rektor No. 11872/UN25/LT/2020 dengan Surat Penugasan No. 2838/UN25.3.1/LT/2020 untuk Hibah KeRis 2020.

\section{DAFTAR PUSTAKA}

Ahmad P, Ashraf M, Younis M, Hu X, Kumar A, Akram NA, Al-Qurainy F (2012) Role of transgenic plants in agriculture and biopharming. Biotechnol Adv 30: 524540.

10.1016/j.biotechadv.2011.09.006

Ali S, Qing-Zhong X, Xian-Yin Z (2004) Assessment of various factors involved in the tissue culture system of rice. Rice Sci 11: 345-349. Corpus ID: 54818359

Azizah KA, Restanto DP, Sugiharto B (2017) Enhancement of regeneration efficiency through callus induction media using 2,4dicholorophenoxyacetic acid in indica rice (Oryza sativa L. var. Ciherang). J Ilmu Dasar 18: 91-98. doi:

\subsection{4/jid.v18i2.2592}

Ben Amer IM, Börner A (1997) The relationship between green spot initiation and plantlet regeneration of wheat callus grown under short-term conditions. Plant Cell Tiss Organ Cult 50: 67-69. doi: 10.1023/A:1005855912655

Binte Mostafiz S, Wagiran A (2018) Efficient callus induction and regeneration in selected indica rice. Agronomy 8: 7794. doi: 10.3390/agronomy 8050077

Cortleven A, Schmülling T (2015) Regulation of chloroplast development and function by cytokinin. J Exp Bot 66: 4999-5013 doi: 10.1093/jxb/erv132

Fanata WID, Lee $\mathrm{KH}$, Son $\mathrm{BH}$, Yoo JY, Harmoko R, Ko KS, Ramasamy NK, Kim KH, Oh DB, Jung HS, Kim JY, Lee SY, Lee KO (2013) N-glycan maturation is crucial for cytokinin-mediated development and cellulose synthesis in Oryza sativa. Plant J 73: 966-979. doi: 10.1111/tpj.12087

Feng F, Li Y, Qin X, Liao Y, Siddique KHM (2017) Changes in rice grain quality of indica and japonica type varieties released in China from 2000 to 2014. Front. Plant Sci 8: 1863. doi: 10.3389/fpls.2017.01863

Fraiture MA, Roosens NHC, Taverniers I, De Loose M, Deforce D, Herman P (2016) Biotech rice: Current developments and future detection challenges in food and feed chain. Trends Food Sci Technol 52: 66-79. doi: 10.1016/j.tifs.2016.03.011

He Z, Xia X, Peng S, Lumpkin TA (2014) Meeting demands for increased cereal production in China. J Cereal Sci 59: 235-244. doi: 10.1016/j.jcs.2013.07.012

Hiei Y, Komari T (2008) Agrobacteriummediated transformation of rice using immature embryos or calli induced from mature seed. Nat Protoc 3: 824-834. doi: 10.1038/nprot.2008.46

Hoque ME, Ali MS, Karim NH (2007) Embryogenic callus induction and regeneration of elite Bangladeshi indica rice cultivars. Plant Tiss Cult Biotechnol 17: 65-70. doi: 10.3329/ptcb.v17i1.1122

Huang WL, Lee CH, Chen YR (2012) Levels of endogenous abscisic acid and indole-3-acetic acid influence shoot 
organogenesis in callus cultures of rice subjected to osmotic stress. Plant Cell Tiss Organ Cult 108: 257-263. doi: 10.1007/s11240-011-0038-0

Joyia FA, Khan MS (2013) Scutellum-derived callus-based efficient and reproducible regeneration system for elite varieties of indica rice in Pakistan. Int $\mathrm{J}$ Agric Biol (Pakistan) 15: 27-33

Lee ST, Huang WL (2014) Osmotic stress stimulates shoot organogenesis in callus of rice (Oryza sativa L.) via auxin signaling and carbohydrate metabolism regulation. Plant Growth Regul 73: 193204. doi: 10.1007/s10725-013-9880-x

Libin A, King PJ, Ong KH, Chubo JK, Sipen $P$ (2012) Callus induction and plant regeneration of Sarawak rice (Oryza sativa L.) variety Biris. Afr J Agric Res 7: 4260-4265. doi: 10.5897/ajar12.587

Mitsuoka $\mathrm{K}$, Honnda $\mathrm{H}$, Xing $\mathrm{XH}$, Unno $\mathrm{H}$ (1994) Effect of intracellular 2,4-D concentration on plantlet regeneration of rice (Oryza sauva L.) callus. Appl Microbiol Biotechnol 42: 364-366. doi: 10.1007/BF00902743

Mohammed S, Samad AA, Rahmat Z (2019) Agrobacterium-mediated transformation of rice: Constraints and possible solutions. Rice Sci 26: 133146. doi: 10.1016/j.rsci.2019.04.001

Rahman ZA, Ramli A, Hosni $H$, Kamaruzaman $\mathrm{R}$, Seman ZA, Othman AN, Zainal Z, Uddain J, Subramaniam $S$ (2015) Efficient plant regeneration of Malaysian aromatic rice (Oryza sativa L.) through somatic embryogenesis. Emirates J Food Agric 27: 857-863. doi: 10.9755/ejfa.2015-07-535

Sah SK, Kaur A (2013) Genotype independent tissue culture base line for high regeneration of japonica and indica rice. Res J Biotechnol 8: 96-101

Sah SK, Kaur A, Sandhu JS (2014a) High frequency embryogenic callus induction and whole plant regeneration in japonica rice Cv. Kitaake. J Rice Res 2: 125. doi: 10.4172/jrr. 1000125

Sah SK, Kaur A, Kaur G, Cheema GS (2014b) Genetic transformation of rice: Problems, progress and prospects. $J$ Rice Res 3: 132. doi: 10.4172/23754338.1000132

Sahoo KK, Tripathi AK, Pareek A, Sopory SK, Singla-Pareek SL (2011) An improved protocol for efficient transformation and regeneration of diverse indica rice cultivars. Plant Methods 7: 49. doi: 10.1186/1746-4811-7-49

Shahsavari E, Maheran AA, Akmar ASN, Hanafi MM (2010) The effect of plant growth regulators on optimization of tissue culture system in Malaysian upland rice. Afr J Biotechnol 9: 20892094. doi: 10.5897/AJB10.1925

Sidorov VA (2013) Plant tissue culture in biotechnology: Recent advances in transformation through somatic embryogenesis. Biotechnol Acta 6: 118131. doi: 0.15407/biotech6.04.118

Wani SH, Sanghera GS, Gosal SS (2011) An efficient and reproducible method for regeneration of whole plants from mature seeds of a high yielding Indica rice (Oryza sativa L.) variety PAU 201. $N$ Biotechnol 28: 418-422. doi: 10.1016/j.nbt.2011.02.006

Zhao W, Zheng S, Ling HQ (2011) An efficient regeneration system and Agrobacterium-mediated transformation of Chinese upland rice cultivar Handao297. Plant Cell Tiss Organ Cult 106: 475-483. doi: 10.1007/s11240-011-9946-2 